\title{
Reproductive biology of Thamnodynastes hypoconia (Serpentes: Dipsadidae) in Brazilian subtemperate wetlands
}

\author{
MARLUCI M. REBELATO ${ }^{1}$, GLÁUCIA M.F. PONTES ${ }^{2}$ and ALEXANDRO M. TOZETTI ${ }^{3}$ \\ ${ }^{1}$ Instituto de Biociências, Departamento de Zoologia, Laboratório de Herpetologia, Universidade Federal do \\ Rio Grande do Sul, Avenida Bento Gonçalves, 9500, Agronomia, 91501-970 Porto Alegre, RS, Brasil \\ ${ }^{2}$ Setor de Herpetologia, Museu de Ciências e Tecnologia da Pontifícia Universidade Católica do Rio Grande \\ do Sul (MCP), Avenida Ipiranga, 6681, Prédio 40, Partenon, 90619-900 Porto Alegre, RS, Brasil \\ ${ }^{3}$ Laboratório de Ecologia de Vertebrados Terrestres, Universidade do Vale do Rio dos \\ Sinos, Avenida Unisinos, 950, 93022-000 São Leopoldo, RS, Brasil
}

Manuscript received on November 27, 2014; accepted for publication on November 27, 2015

\begin{abstract}
This study aimed to describe the reproductive biology of populations of Thamnodynastes hypoconia in subtemperate wetlands based on macroscopic analyses of their gonads. We analyzed 101 specimens from the southernmost regions of Brazil. The males had a greater snout-vent length, but the females reached sexual maturity with a greater body size. The reproductive cycle of the females was seasonal, with secondary vitellogenesis occurring between the winter and spring (May-October). Based on macroscopic analysis of gonads, data suggests that males have a continuous reproductive cycle. Parturition occurs between the late summer and early fall (January-April). The clutch size ranged between 4 and 16 embryos and showed no relationship with the female's body size. The recorded reproductive frequency of T. hypoconia is low (38 $\%$ ) compared to other phylogenetically related species. Conversely, the studied populations appear to have a high reproductive success because it is an abundant species in the study site.
\end{abstract}

Key words: ecology, Pampa, reproductive cycle, sexual maturity, snakes.

\section{INTRODUCTION}

Reproduction is one of the primary components of the life history of an organism, acting directly on the population dynamics (Seigel and Ford 1987, Holycross and Goldberg 2001). Because they are ectotherms, the activities of snakes, such as moving, foraging and some metabolic processes, are directly affected by the climate (Mushinsky and Hébrard 1977, Nelson and Gregory 2000). Abiotic

Correspondence to: Marluci Müller Rebelato

E-mail: mmrebelato@yahoo.com.br variables, such as temperature and relative humidity, rainfall, photoperiod and lunar cycle, may affect the reproductive cycle of snakes (Houston and Shine 1994, Daltry et al. 1998, Sun et al. 2000). Snakes can also respond to changes in their food supply (Fitch 1982) or exhibit a pattern determined by its phylogenetic history (Seigel and Ford 1987, Brown and Shine 2006). From an evolutionary point of view, the selective pressures in temperate regions favor the establishment of seasonal reproductive cycles to synchronize the reproductive peak with the warmer seasons of the year (Shine 1985, 
Duvall et al. 1982, Mathies 2011). In turn, the greater climatic stability and the predominance of higher temperatures in tropical regions appear to favor the establishment of continuous reproductive cycles (Fitch 1980, Seigel and Ford 1987, Barros et al. 2012). Evidently, not all tropical species have continuous reproductive cycles. In fact, in many tropical regions, there are snake species with seasonal reproductive cycles (Fitch 1982, AlmeidaSantos and Salomão 2002, Shine 2003, Mathies 2011) as well as continuous cycles (Saint-Girons 1982). Seasonal reproductive cycles would be favored, even in the tropics, in situations where there is marked climate seasonality that results in fluctuations in the availability of food resources (Shine 2003).

The concentration of the reproductive peak at certain times of the year would increase the survival rate of offspring, for example, by providing synchrony between the births and periods with a higher food supply (Marques et al. 2001, Valdujo et al. 2002). In addition, the relatively low winter temperatures (frequently close to $0^{\circ} \mathrm{C}$ ) in the subtemperate regions of southern Brazil would restrict any continuous reproduction patterns in the resident snake species. During the winter, the average temperatures of this region tend to stay below the optimal temperature for embryonic development (Tinkle and Gibbons 1977, Shine 1995). Therefore, viviparous species tend to be less affected because they can more accurately control the temperature of their embryos (Seigel and Ford 1987). Because of this, the study of the reproductive cycle of viviparous snakes in colder climates can generate important data for understanding the evolutionary and adaptive processes of the reproductive biology of ectotherms.

One of the numerically dominant species in the southernmost Brazilian wetlands is Thamnodynastes hypoconia. It is a small snake belonging to the Tachymenini tribe (see Zaher et al. 2009, Grazziotin et al. 2012), and it is nocturnal, semi-ar- boreal and viviparous (Achaval and Olmos 2003). Studies in regions with subtropical-temperate climates revealed a seasonal reproductive cycle in the females of $T$. hypoconia, while in the males, the cycle can be continuous or seasonal (Bellini et al. 2013, 2014). However, due to its wide geographic distribution, which includes northeastern, midwestern, southeastern and southern Brazil, Paraguay, Uruguay and Argentina (Franco 1999, Giraudo 2001), it is possible that different populations show variations in their reproductive patterns. Due to their relative abundance in many of the wetlands of southern Brazil, it is assumed that this species possesses an efficient reproductive strategy. Moreover, being viviparous, this species is a good model to assess the reproductive patterns of Neotropical snakes, which are still rarely studied under these climatic conditions. The aim of this study was to describe the reproductive biology of Thamnodynastes hypoconia in the subtemperate, southernmost humid environments of Brazil.

\section{MATERIALS AND METHODS}

The study was developed by analyzing the Thamnodynastes hypoconia specimens from the Herpetological Collections of the Universidade Federal do Rio Grande (CHFURG) and the Museu de Ciências e Tecnologia da Pontifícia Universidade Católica do Rio Grande do Sul (MCP) (Appendix). Because there is evidence that throughout its distribution T. hypoconia may represent a taxonomic complex, only specimens coming from the southernmost Brazilian regions were selected, particularly the city of Rio Grande, Rio Grande do Sul $\left(32^{\circ} 02^{\prime} 06^{\prime \prime} \mathrm{S}, 52^{\circ} 05^{\prime} 55^{\prime \prime} \mathrm{O}\right)$, where there is taxonomic and climatic homogeneity.

To increase the sample size, additional captures were made in a preserved wetland area, the Estação Ecológica do Taim (ESEC Taim), which is also located in an area in the municipality of Rio Grande (32 $50^{\prime} \mathrm{S}$ and $\left.52^{\circ} 26^{\prime} \mathrm{O}\right)$. The region 
of origin of all of the samples is characterized by the predominance of wetlands (i.e., ponds and permanent and temporary wetlands) that are associated with a mosaic of dunes, fields and forest sandbanks (Waechter 1985). The homogeneity of the landscape is primarily affected by the flood cycles when the wetlands and fields become waterlogged (Gomes et al. 1987). Despite the regular distribution of rainfall throughout the year, the peak flood season is generally between June and August. The climate is classified as humid subtemperate, with an average annual temperature of $18.1^{\circ} \mathrm{C}$ (Maluf 2000). The seasons are well defined and may have periods of drought in the spring, and the average annual rainfall is $1162 \mathrm{~mm}$ (Maluf 2000).

Collections to complement the number of specimens occurred between April 2012 and March 2013 and were conducted using a visual search method (Campbell and Christman 1982). The snakes were collected under permits from SISBIO (no. 32620-1 and 37410-1), euthanized with the use of a barbiturate anesthetic, fixed in a solution of 10 $\%$ formalin and preserved in $70 \%$ alcohol (Heyer et al. 1994) before assessing the reproductive state.

In the laboratory, each individual was measured for their snout-vent length (SVL, in $\mathrm{mm}$ ) using a measuring tape (accuracy of $1 \mathrm{~mm}$ ). To collect the reproductive data, the specimens were dissected via an incision in the median ventral region. For the females, the following information was recorded: the diameter of the largest ovarian follicle $(\mathrm{mm})$; the largest diameter of the embryo inside the oviduct ( $\mathrm{mm}$ ); the number of follicles in secondary vitellogenesis (secondary follicles) or the number of embryos and the condition of oviduct (pleated or extended). The determination of the follicles in secondary vitellogenesis was done posteriorly using a scatterplot of the follicle measurements (Almeida-Santos et al. 2014). The follicles $\geq 5$ $\mathrm{mm}$ were considered to be secondary follicles, a value consistent with the previously recorded data for the species (Bellini et al. 2013, 2014). Ovarian follicles $<5 \mathrm{~mm}$ were considered to be in primary vitellogenesis in the follicles (primary follicles). Embryos in early development in the follicles were distinguished by observing their location in the reproductive tract, which was restricted to the oviduct. For the males, the following information was recorded: the length, width and thickness of the right and left testes $(\mathrm{mm})$; the diameter of the distal portion of the right deferent duct ( $\mathrm{mm}$ ) (see Pizzatto 2003, Almeida-Santos et al. 2006); and the condition of the deferent duct (coiled or not). The gonads were measured using a digital caliper (accuracy of $0.1 \mathrm{~mm}$ ). The volume of the testicles was used as an indicator of spermatogenic activity (Pizzatto et al. 2008b, Gomes and Marques 2012, Bellini et al. 2013). The testicular volume was estimated using the formula for the volume of an ellipsoid (Pleguezuelos and Feriche 1999). Despite of the questionable accuracy of the testicles volume measure for a real evaluation of male reproductive cycle, this is a wide spread method facilitating comparisons between our and different studies (Pizzatto 2005, Bellini et al. 2013, 2014).

The females were considered to be mature when they presented with secondary follicles $(\geq$ $5 \mathrm{~mm}$ follicles), embryos or pleated oviducts, indicating recent parity (Pizzatto et al. 2008a, Leite et al. 2009). The males were considered to be mature when they had turgid testes and coiled deferent ducts, indicating the presence of sperm (Shine 1980, Almeida-Santos et al. 2014). The reproductive cycle of the females was characterized by their distribution during the year, the size of their ovarian follicles and the presence of embryos in their oviducts (Shine 1977, 1988). The fecundity (litter size) was determined based on the number of embryos found in the oviduct, i.e., the actual fertility (see Mesquita et al. 2013, Almeida-Santos et al. 2014, Braz et al. 2014). The reproductive frequency of the females was estimated by the percentage of reproductive females (with follicles 
$\geq 5 \mathrm{~mm}$ or embryos) in the sample (Pizzatto 2005). In the males, the volume change of the testes throughout the year reflected their reproductive cycle because the testes typically increase in size during peak spermatogenic activity (Pizzatto et al. 2007a).

To infer the recruitment season of the newborns with respect to the collection dates, the SVL values of newborn and juvenile specimens received from the collections throughout the year (see Marques et al. 2001) were plotted on a scatterplot for a visual definition of the cutoff between the newborns and young individuals/adults. Specimens with lower SVL values were considered to be newborns or young snakes.

To determine whether there was a significant difference in the body size between the adult males and females, the SVL measurements were compared using analysis of variance (ANOVA). To test the existence of seasonality in the reproductive cycles of the females and males, circular statistical analysis (Zar 1999) was used via the ORIANA 2.02 program (Kovach 2004). The months were converted to angles ranging from zero degrees (January) to $330^{\circ}$ (December) with intervals of 30 . In this analysis, each angle (month) was associated with the number of secondary follicles or embryos and the number of pairs of coiled deferent ducts recorded each month. The months with the highest frequency of these records corresponded to peaks of reproductive activity of the males and females. Using this method, we estimated the following: (1) the vector average $(\mu)$, which corresponds to the average period of the year in which most of the snakes were reproducing; (2) the circular standard deviation (SD); and (3) the vector $r$, which is an average concentration of the data around the circle (years), ranging from 0 (scattered data) to 1 (data concentrated in the same direction). The uniformity of the Rayleigh test ( $\mathrm{z}$ ) was used to calculate the probability of the null hypothesis (the data are distributed uniformly around the analyzed cycle) $(p>0.05)$ (Zar 1999). A significant result of the Rayleigh test $(\mathrm{p}<0.05)$ indicates that the data are not uniformly distributed and there is a significant average angle or average direction (Kovach 2004), i.e., there is seasonality in the reproductive cycles of the studied snakes.

To verify whether there is a relationship between the female size and the number of embryos she produces (actual fecundity), a linear correlation analysis was performed (Seigel and Ford 1987, Shine 1992). The volume of the testes and the diameter of the deferent ducts are directly related to the size of the males and their allometric relationships, as they differ throughout the reproductive cycle (Shine et al. 1998). Therefore, to remove the effect of the size of the individuals on the variation in the diameter and volume measurements described above, we calculated the total residue of the volume of the testes (right + left) and the diameter residue of the right deferent duct relative to the SVL throughout the year. The residual variation in the total volume of the testicles and the diameter of the right deferent duct between the warm months (spring/ summer; October-March) and the cold months (autumn/winter; April-September) was analyzed using the Mann-Whitney test (U test) (Zar 1999) to indicate the reproductive cycle of the males throughout the year (Pizzatto and Marques 2002).

\section{RESULTS}

Of the 101 individuals that were analyzed (56 specimens from collections and 45 captured during this study), 63 were males (36 adults and 27 young) and 38 were females ( 31 adults and 7 young). The average SVL of the adult males was $387.08 \mathrm{~mm}$ $(\mathrm{SD}=49.33$; range $=270-480 \mathrm{~mm})$ and was significantly higher than that of the females $\left(\mathrm{F}_{1.64}\right.$ $=5.48 ; \mathrm{p}=0.02)$, which was $361.94 \mathrm{~mm}(\mathrm{SD}=$ 35.75 ; range $=300-410$ ). Although they were smaller, the females reached a greater body size at sexual maturity $(\mathrm{SVL}=300 \mathrm{~mm})$ than the males $(\mathrm{SVL}=270 \mathrm{~mm})$. 
A total of $81.57 \%$ of the females were mature (i.e., presence of secondary follicles, embryos and/ or pleated oviduct). The circular statistics showed that the reproductive cycle of the females was seasonal $(p=0.03)$, with embryos concentrated between October and December (spring and summer) (Table I; Figures 1 and 2). Primary follicles $(<5 \mathrm{~mm})$ were found throughout the year and secondary follicles ( $\geq 5 \mathrm{~mm}$ ) were recorded in May, August and October (winter and spring) (Figures 1 and 2). Secondary follicles were only observed in three females $(9.67 \%)$. No specimens simultaneously presented with secondary follicles and embryos.

TABLE I

Results of the circular statistical analysis testing the seasonality of the reproductive cycles of the females and males of Thamnodynastes hypoconia in southernmost Brazil.

\begin{tabular}{lcc}
\hline Variables & Reproductive females & Reproductive males \\
\hline Number of observations $(n)$ & 11 & 36 \\
\hline Mean angle $(\alpha)$ & $303.592^{\circ}$ & $278.479^{\circ}$ \\
\hline Mean vector length $(r)$ & 0.537 & 0.133 \\
\hline Circular standard deviation $(\mathrm{SD})$ & $63.876^{\circ}$ & $115.162^{\circ}$ \\
\hline Rayleigh test of uniformity $(p)$ & 0.03 & 0.53 \\
\hline
\end{tabular}

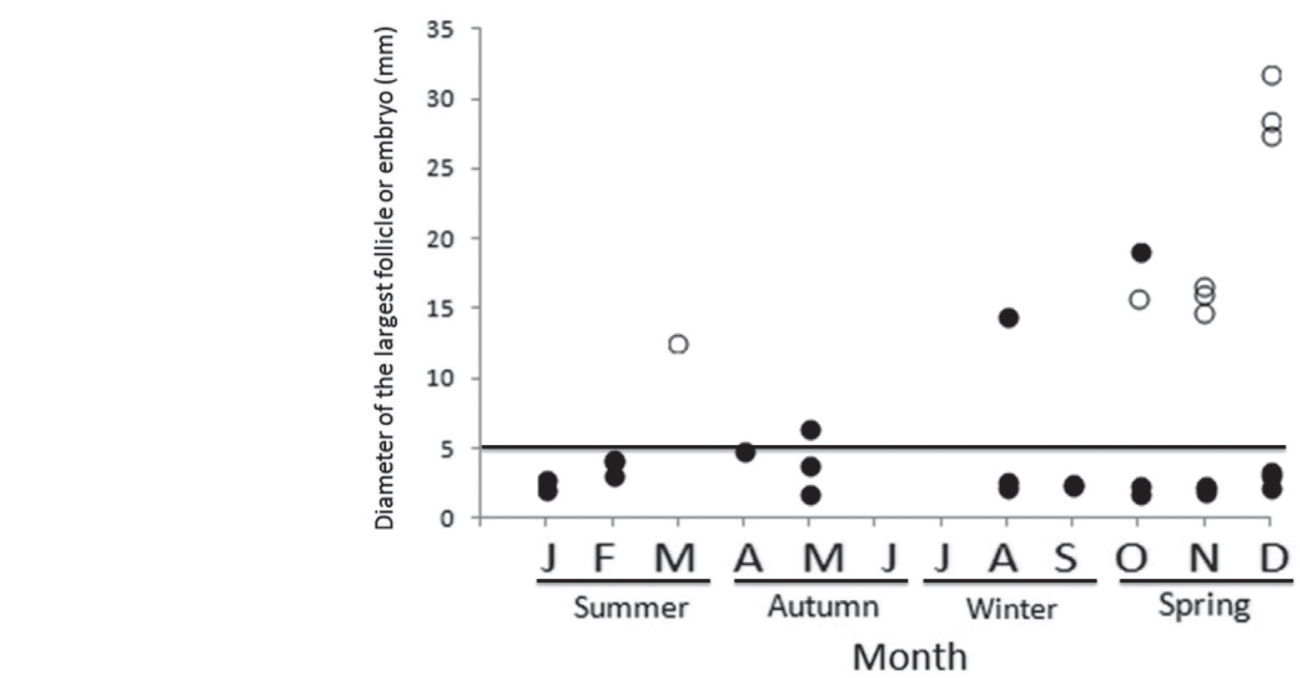

Figure 1 - The seasonal variation in the diameter of the largest ovarian follicle and the largest embryo of females from Thamnodynastes hypoconia living in southernmost Brazil. Filled circles: ovarian follicle; open circles: embryo. The horizontal line indicates the size limit between the primary $(<5$ $\mathrm{mm})$ and secondary ( $\geq 5 \mathrm{~mm})$ follicles.

Secondary vitellogenesis
Embryos
Parturition
Indicator of spermatogenesis

Figure 2 - The stages of the reproductive cycles of male and female Thamnodynastes hypoconia (living in southernmost Brazil) during the different months of the year. Black bars: registered data; gray bar: inferred data. 
The actual fecundity or litter size (number of embryos) was $7.6 \pm 4.7$ (range $=4-16$ ) embryos per female, which showed an average diameter of $20.46 \pm 7.48 \mathrm{~mm}$ (range $=12.64$ to $31.8 \mathrm{~mm}$ ). There was no relationship between the female SVL value and the fecundity $\left(\mathrm{R}^{2}=0.39 ; \mathrm{p}=0.20 ; \mathrm{n}=\right.$ 8). The reproductive frequency (the percentage of reproductive females in the sample) was $38 \%$, suggesting that more than half of the females that able to reproduce were not reproducing. The smallest individual analyzed had a $120 \mathrm{~mm}$ SVL, and those that showed an SVL $<130 \mathrm{~mm}$ were considered to be newborns and were observed in February (summer). This cutoff point appears to be consistent because a litter of 7 newborns preserved in the Herpetological Collection of MCP (coming from a nearby locality but outside of our study area) showed a mean SVL of $115 \mathrm{~mm}$. Other information used to determine the recruitment season included an observation of two females in December (summer) with embryos that were almost at parturition, with an average SVL of $85 \mathrm{~mm}$.

A total of $42.86 \%$ of the analyzed males were mature (i.e., presence of turgid testes and convoluted deferent ducts). There was no significant variation between the volumes of the right and left testes $(\mathrm{U}=560 ; \mathrm{p}=0.32 ; \mathrm{N}=36)$. The circular statistic suggests that the male reproductive cycle was continuous ( $p=0.53)$ (Table I; Figure 2). There was also no significant difference in the variation in the residue of the diameter of the right deferent duct between the hot and cold months ( $U=159$; $p$ $=0.94 ; \mathrm{N}=36$ ) nor in the variation in the residue of the total volume of the testicles $(\mathrm{U}=159 ; \mathrm{p}=$ $0.94 ; \mathrm{N}=36$ ).

\section{DISCUSSION}

Our data showed that the males of Thamnodynastes hypoconia are larger than the females, which is common in species where there is male combat (Shine et al. 2000). However, this dimorphism in size is not unique for species with male-male combat (Joy and Crews 1988, Crews 2000). In addition, there was no evidence obtained in the field that the males of $T$. hypoconia compete physically for females to mate with. An alternative explanation is that the larger body size of the males could provide metabolic advantages, such as low energy cost per unit weight. Therefore, the males tend to be more vagile than females, at least during the breeding season, as has already been noted in some species of Neotropical viperids (Tozetti et al. 2009, Tozetti and Martins 2013). Males that are larger than females are found in several species of Tachymenini (Bailey 1981), excluding Thamnodynastes strigatus (A. Bizerra, unpublished data) and Tomodon dorsatus (Bizerra et al. 2005). Nonetheless, in Tachymenini, there are cases where there is no difference in size between the sexes, such as in Gomesophis brasiliensis (Oliveira et al. 2003), Thamnodynastes chaquensis, T. hypoconia and T. strigatus (Bellini et al. 2014).

Females of T. hypoconia reached sexual maturity with a greater body size than the males. This pattern has been recorded in other populations of the species in Argentina, Uruguay and Paraguay (Bellini et al. 2013, 2014), as well as in T. chaquensis and T. strigatus (Bellini et al. 2014). This pattern suggests that sexual maturity occurs later in females than in males (see Shine 1978, Vitt 1983). One possible explanation for this difference is the fact that the preparation for reproduction is more energetically costly for females than for males (Madsen and Shine 1994, Luiselli et al. 1996a, b). The possibility that males have a lower metabolic cost associated with reproduction is enhanced by our data that show sexually active males throughout the year. A later maturation in females would lead to a later start of the reproductive process, giving rise to specimens with larger body sizes and favoring larger litters (Madsen and Shine 1993, Shine 1993). However, we found no relationship between the females' size and their litter size, reinforcing the data of Bellini et al. $(2013,2014)$. The clutch size 
ranged from 4 to 16 embryos per female, similar to the results of Achaval and Olmos (2003), Carreira et al. (2005) and Bellini et al. (2013, 2014). According to these authors, these values indicate that $T$. hypoconia have a low fecundity when compared with other snakes, including those that are phylogenetically related, such as $T$. dorsatus (4 to 26 embryos per female) (Bizzera et al. 2005). The lower number of embryos may be related to the semi-arboreal habitat of T. hypoconia (Achaval and Olmos 2003), due possible limitations in the use of the vegetation by very heavy females (Pizzatto et al. 2007b).

The reproductive cycle of the females was seasonal, with embryos restricted to the warmer months. However, the low number of available females in June-July (colder months), limited the evaluation of the reproductive status during this single period. However, the examined specimens (including those from the collections) were captured through regular surveys using homogeneous sampling efforts. Therefore, the low number of specimens captured in June-July suggests a period when the females reduce their activity or mobility (Santos et al. 2012). This behavior is likely associated with the need to reduce energy costs and the accumulation of yolk in the follicles.

The parturition events occurred between late summer and early fall (January-April). The hypothesis that mating occurs in spring and births in the summer has already been proposed in other studies (Gudynas 1981, Carreira et al. 2005, Sawaya et al. 2008). Despite the low number of recorded secondary follicles $(\mathrm{N}=3)$, there was a trend towards an increase in the diameter over the months from May to October (late fall to midspring), corroborating the data of Bellini et al. (2013). However, the peak reproduction periods of T. hypoconia can differ between populations (Bellini et al. 2014). In addition to variations throughout the year, geographical variations appear to interfere more broadly with the reproductive cycle. For example, in the southernmost regions of Brazil, a seasonal reproductive cycle was reported in females from Erythrolamprus poecilogyrus (D. Selbach, unpublished data), whereas a continuous cycle was recorded in a population in the southeast (Pinto and Fernandes 2004). Therefore, it is possible that in the southernmost regions of Brazil, the peak reproductive activity occurs during the warmer months of the year, avoiding the relatively low winter temperatures. Furthermore, it is suggested that the seasonal cycle of reproduction favors the synchrony between the birth of the newborns and the period with the highest prey offering (Marques et al. 2001, Valdujo et al. 2002).

All of the examined individuals were captured recently (less than 4 years ago), reducing the risks of deformities in the gonads, which would interfere with the interpretation of their cycle (AlmeidaSantos et al. 2014). However, we reinforce the need of histological analyzes for a real determination of the spermatogenesis peak (Almeida-Santos et al. 2014).

Many studies have evaluated the reproductive patterns of snakes in different climatic regions (Pizzatto et al. 2008a). Generally, in temperate areas, snakes have reproductive peak in the warmer months of the year, while in tropical areas these peaks are distributed more irregular throughout the year (Fitch 1982, Seigel and Ford 1987). Despite methodological limitations, our estimates indicate that the reproductive pattern of males in T. hypoconia tends to be continuous. This pattern was not expected due to the relatively cold climate (subtemperate) of the Brazilian southernmost (see Seigel and Ford 1987). However, the seasonal cycle has been registered for females. Confirmation of the male cycle, however, depends on histological analyzes of their gonads. Thus, the plasticity of the reproductive cycle in Thamnodynastes has been observed in other studies evaluating different populations (Belini et al. 2013, 2014). These data reinforce the idea that the phylogenetic affinities do 
not support reproductive similarities within a genus (Pizzatto et al. 2008a). This observation shows the importance of other elements in the definition of reproductive cycles, including climate complexity (Greene 1997) and food availability (Santos et al. 2005, Seigel and Ford 1987). Thus, climatic factors seem to have predominant action on these cycles (Pizzatto and Marques 2002, 2006).

Despite the potential of males to reproduce throughout the year, the same trend was not observed in the females, which suggests that there is only one breeding season per year. This hypothesis is reinforced by the fact that there were no females exhibiting simultaneous secondary follicles and embryos (Brown and Shine 2006, Pizzatto et al. 2008b). On the converse, the low proportion of registered breeding females indicates that the reproductive cycles are biennial or multi-year, which is reinforced by the simultaneous occurrence of pregnant females and mature females without secondary follicles or embryos (Bellini et al. 2013, 2014). Our data reveled a low proportion of reproductive females of $T$. hypoconia in the sampling population, similar to that recorded by Bellini et al. $(2013,2014)$, who obtained a proportion of reproductive females of $48 \%$. In our study site, previous sampling using pitfall traps and visual sampling (unpublished data) demonstrated that $T$. hypoconia is one of the most abundant snake species. Being a viviparous snake should contribute to their reproductive success and consequently, to their high population density in the region (Santos et al. 2012). Moreover, while it is considered to be a relatively cold climate by Neotropical standards, even during the winter, the daily peak temperatures often exceed $25^{\circ} \mathrm{C}$, favoring thermoregulation. Therefore, it is possible that the reproductive success is due to the continuous cycle of males and also the viviparity of the species, which would allow adjustments in the peak reproduction period of the females throughout its distribution area.

\section{ACKNOWLEDGMENTS}

The authors acknowledge the field assistance provided by Daniela Selbach and Paulo Ellert and the support provided by the employees of the Estação Ecológica do Taim during the fieldwork. Additional thanks are provided to Conselho Nacional de Desenvolvimento Científico e Tecnológico (CNPq) and Coordenação de Aperfeiçoamento de Pessoal de Nível Superior (CAPES) for their financial support for this study.

\section{RESUMO}

O estudo teve como objetivo descrever a biologia reprodutiva das populações de Thamnodynastes hypoconia em ambientes subtemperados úmidos baseado em análises macroscópicas das suas gônadas. Foram analisados 101 espécimes provenientes do extremo sul do Brasil. Os machos tiveram maior comprimento rostro-cloacal, mas as fêmeas atingiram a maturidade sexual com maior tamanho corpóreo. O ciclo reprodutivo das fêmeas foi sazonal, com vitelogênese secundária ocorrendo entre o inverno e a primavera (Maio-Outubro). Baseado na análise macroscópica das gônadas, os dados sugerem que os machos tenham ciclo reprodutivo contínuo. O parto ocorre entre o fim do verão e início do outono (Janeiro-Abril). O tamanho da ninhada variou entre 4 e 16 embriões e não apresentou relação com o tamanho do corpo da fêmea. A frequência reprodutiva de T. hypoconia foi baixa (38\%) quando comparada com espécies filogeneticamente próximas. Por outro lado, as populações estudadas parecem ter um alto sucesso reprodutivo, uma vez que é uma espécie muito abundante no local de estudo.

Palavras-chave: ecologia, Pampa, ciclo reprodutivo, maturidade sexual, serpentes.

\section{REFERENCES}

ACHAVAl F AND Olmos A. 2003. Anfibios y reptiles Del Uruguay. 2 ed., Graphis Impresora, Montevideo, Uruguay, $160 \mathrm{p}$.

AlmeIDA-SANTOS SM, BRAZ HB, SANTOS LC, SUEIRO LR, BARROS VA, ROJAS CA AND KASPEROVICZUS KN. 2014. Biologia reprodutiva de serpentes: recomendações para a coleta e análise de dados. Herpetologia Brasileira 3: 14-24.

ALMEIDA-SANTOS SM AND SALOMÃO MG. 2002. Reproduction in neotropical pitvipers, with emphasis on species of 
the genus Bothrops. In: Schuett GW et al. (Eds), Biology of the Vipers. Eagle Mountain Publishing, Carmel, p. 445462.

AlmeidA-SANTOS SM, PIZZATTO L AND MARQUES OAV. 2006. Intra-sex synchrony and inter-sex coordination in the reproductive timing of the Atlantic coral snake Micrurus corallinus (Elapidae) in Brazil. Herpetol J 16: 371-376.

BAILEY J. 1981. Notes on the genus Thamnodynastes. I Simpósio Internacional sobre Serpentes em Geral e Artrópodes Peçonhentos, Instituto Butantan, São Paulo, p. 31.

BARros VA, SuEIRo LR AND ALMEIDA-SANTOS SM. 2012. Reproductive biology of the neotropical rattlesnake Crotalus durissus from northeastern Brazil: a test of phylogenetic conservatism of reproductive patterns. Herpetol J 22: $97-104$.

BELLINI GP, ARZAMENDIA V AND GIRAUDO AR. 2013. Ecology of Thamnodynastes hypoconia in Subtropical-Temperate South America. Herpetologica 69: 67-79.

BELlini GP, GIRAUdo AR AND ARZAMENDiA V. 2014. Comparative ecology of three species of Thamnodynastes (Serpentes, Dipsadidae) in subtropical-temperate South America. Herpetol J 24: 87-96.

BIZERRA A, MARQUES OAV AND SAZIMA I. 2005. Reproduction and feeding of colubrid snake Tomodon dorsatus from south-eastern Brazil. Amphib-reptil 26: 33-38.

BRAZ HB, KASPEROVICZUS KN AND ALMEIDA-SANTOS SM. 2014. Reproductive ecology and diet of the fossorial snake Phalotris lativittatus in the Brazilian Cerrado. Herpetol J 24(1): 49-57.

BROWN GP AND SHINE R. 2006. Why do most tropical animals reproduce seasonally? Testing hypotheses on an Australian snake. Ecology 87: 133-143.

CAMPBELL HW AND CHRISTMAN SP. 1982. Field techniques for herpetofaunal community analysis. In: Scott-Jr NJ (Ed), Herpetological Communities: a Symposium of the Society for the Study of Amphibians and Reptiles and the Herpetologist's League, U.S. Fish and Wildlife Service, Federal Government Series: Wildlife Research Report 13: 193-200.

CARreira S, MENEGHEK M AND ACHAVAL F. 2005. Reptiles de Uruguay. DIRAC/Facultad de Ciencias, Montevideo, Uruguay, p. 639.

CREWS D. 2000. Reply to Shine et al. (2000). Anim Behav 59: F12.

DALTRY JC, Ross T, THORPE RS AND WUSTER W. 1998. Evidence that humidity influences snake activity patterns: A field study of the Malayan pit viper Calloselasma rhodostoma. Ecography 21: 25-34.

DUVALL D, GUILLETTE JR LJ AND JONES RE. 1982. Environmental control of reptilian reproductive cycles. In: Gans $\mathrm{C}$ and Pough H (Eds), Biology of the Reptilia, Academic Press: New York, p. 201-231.

FITCH HS. 1980. Reproductive strategies of reptiles. In: Murphy JB and Collins JT (Eds), Reproductive biology and diseases of captive reptiles, SSAR Contribuitions to Herpetology, p. 25-31.
FITCH HS. 1982. Reproductive cycles in tropical reptiles. Occasional papers of the Museum of Natural History, the University of Kansa, 53 p.

FRANCO FL. 1999. Relações fillogenéticas entre os gêneros da tribo Tachymenini Bailey, 1967 (Serpentes, Colubridae). Tese de Doutorado, Universidade de São Paulo, São Paulo, Brasil, 252 p.

GIRAUdo AR. 2001. Serpientes de la Selva Paranaense y del Chaco Húmedo. Buenos Aires, LOLA, 328 p.

GOMES A, TRICART J AND TRAUTMANN J. 1987. Estudos ecodinâmico da Estação Ecológica do Taim e seus arredores. Editora da Universidade, Universidade Federal do Rio Grande do Sul, Porto Alegre, Brasil, 84 p.

Gomes CA AND MARQues OAV. 2012. Food habits, reproductive biology, and seasonal activity of the dipsadid snake, Echinanthera undulata (Wied, 1824), from the Atlantic forest in southeastern Brazil. South Am J Herpetol 7: 233-240.

GraZZIOTIN FG, ZAHER H, MURPHY RW, SCROCCHI G, BENAVIDES MA, ZHANG Y AND BONATTOH SL. 2012. Molecular phylogeny of the New World Dipsadidae (Serpentes: Colubroidea): A reappraisal. Cladistics 1: 1-23.

GREENE HW. 1997. Snakes. The Evolution of Mystery in Nature. University of California Press, Berkeley, California, USA.

GUDYNAS E. 1981. Confirmación de la viviparidad en la Culebra Sepia Thamnodynastes strigilis (Serpentes: Colubridae). Contribuciones en Biología del Centro Educativo Don Orione 5: 1-7.

HEYER WR, DONNELlY MA, MCDIARMID RW, HAYEK LC AND FOSTER MS. 1994. Measuring and monitoring biological diversity: standard methods for amphibians. Washington: Smithisonian Institution Press, 384 p.

HOLYCROSS AT AND GOLDBERG SR. 2001. Reproducion in northern populaions of the Ridgenose Ratlesnake, Crotalus willardi (Serpentes: Viperidae). Copeia 2001: 473-481.

Houston DL AND SHINE R. 1994. Movements and activity patterns of Arafura filesnakes (Serpentes: Acrochordidae) in tropical Australia. Herpetologica 50: 349-357.

JOY JE AND CREWS D. 1988. Male mating success in redsided garter snakes: size is not important. Anim Behav 36: 1839-1841.

KOVACH WL. 2004. Oriana for Windows, version 1.03. Kovach Computer Services, Pentraeth, Wales, U.K.

LEITE PT, NunES SF, KAEFER IL AND CECHIN SZ. 2009. Reproductive biology of the Swamp Racer Mastigodryas bifossatus (Serpentes: Colubridae) in subtropical Brazil. Zoologia 26: 12-18.

LUISELLI L. 1996a. Individual success in mating balls of the grass snake, Natrix natrix: size is important. J Zool 239: 731-740.

LUISELli L, CAPULA M AND SHINE R. 1996b. Reproductive output, costs of reproduction, and ecology of the smooth snake, Coronella austriaca, in the eastern Italian Alps. Oecologia 106: 100-110. 
MADSEN T AND SHINE R. 1993. Costs of reproduction in a population of European adders. Oecologia 94(4): 488-495.

MADSEN T AND SHINE R. 1994. Costs of reproduction influence the evolution of sexual size dimorphism in snakes. Evolution 48: 1389-1397.

MALUF JRT. 2000. Nova classificação climática do Estado do Rio Grande do Sul. RBAgro 8: 141-150.

MARQUES OAV, ETEROVIC A AND ENDO W. 2001. Seasonal activity of snakes in the Atlantic forest in southeastern Brazil. Amphib-reptil 22: 103-111.

MATHIES T. 2011. Reproductive cycles of tropical snakes. In: Aldridge RD and Sever DM (Eds), Reproductive Biology and Philogeny of Snakes. Enfield: Science Publishers, p. 511-550.

MESQUITA PCMD, SÁ-POLIDORO GL AND CECHIN SZ. 2013. Reproductive biology of Philodryas olfersii (Serpentes, Dipsadidae) in a subtropical region of Brazil. Herpetol J 23: $39-44$

MUSHINSKY HR AND HÉBRARD JJ. 1977. The use of time by sympatric water snakes. Can J Zool 55: 1545-1550.

NELSON KJ AND GREGORY PT. 2000. Activity patterns of garter snakes, Thamnophis sirtalis, in relation to weather conditions at a fish hatchery on Vancouver Island, British Columbia. J Herpetol 34: 32-40.

OLIVEIRA JL, BORGES M AND MARQUES OAV. 2003. Gomesophis brasiliensis. Reproduction and Diet. Herpetol Rev 34: 251.

PINTO RR AND FERNANDES R. 2004. Reproductive biology and diet of Liophis poecilogyrus poecilogyrus (Serpentes, Colubridae) from southeastern Brazil. Phyllomedusa 3: 9-14.

PIZZATTO L. 2003. Reprodução de Liophis miliaris (Serpentes: Colubridae) no Brasil: influência histórica e variações geográficas. Dissertação de Mestrado, Universidade Estadual de Campinas, Campinas, São Paulo, 103 p. (Unpublished).

PIZZATTO L. 2005. Body size, reproductive biology and abundance of the rare pseudoboini snakes genera Clelia and Boiruna (Serpentes, Colubridae) in Brazil. Phyllomedusa 4: 111-122.

PizZATTO L, ALMEIDA-SANTOS SM AND MARQUES OAV. 2007a. Biologia reprodutiva de serpentes brasileiras. In: Nascimento LB and Oliveira ME (Eds), Herpetologia no Brasil II, Sociedade Brasileira de Herpetologia, Belo Horizonte, Minas Gerais, Brasil, p. 201-221.

PizZATTO L, ALMEIDA-SANTOS SM AND SHINE R. $2007 \mathrm{~b}$. Life history adaptations to arboreality in snakes. Ecology 88: 359-366.

PIZZATTO L, CANTOR M, LIMA DE OLIVEIRA J, MARQUES OAV, CAPOVILLA V AND MARTINS M. 2008a. Reproductive ecology of Dipsadine snakes, with emphasis on South American species. Herpetologica 64: 168-179.

PIZZATTO L, JORDÃO RS AND MARQUES OAV. 2008b. Overview of reproductive strategies in Xenodontini (Serpentes: Colubridae: Xenodontinae) with new data for Xenodon neuwiedii and Waglerophis merremii. J Herpetol 42: $153-$ 162.

PIZZATTO L AND MARQUES OAV. 2002. Reproductive biology of the false coral snake Oxyrhopus guibei (Colubridae) from southeastern Brazil. Amphib-reptil 23: 495-504.

PIZZATTO L AND MARQUES OAV. 2006. Interpopulational variation in sexual dimorphism, reproductive output, and parasitism of the water snake Liophis miliaris (Colubridae), in the Atlantic forest of Brazil. Amphib-reptil 27: 37-46.

Pleguezuelos JM AND FERICHE M. 1999. Reproductive ecology of the horseshoe whip snake, Coluber hippocrepis, in the southeast of the Iberian Peninsula. J Herpetol 33: 202-207.

SAINT-GIRONS H. 1982. Reproductive cycles of male snakes and their relationships with climate and female reproductive cycles. Herpetologica 38: 5-16.

SANTOS MB, OLIVEIRA MCLM AND TOZETTI AM. 2012. Diversity and habitat use by snakes and lizards in coastal environments of southernmost Brazil. Biota Neotrop 12: 78-87.

Santos X, Llorente GA, Feriche M, Pleguezuelos JM, CASALS F AND SOSTOA A. 2005. Food availability induces geographic variation in reproductive timing of an aquatic oviparus snake (Natrix maura). Amphib-reptil 26: 183-191.

SAWAYA RJ, MARQUES OAV AND MARTINS M. 2008. Composition and natural history of a Cerrado snake assemblage at Itirapina, São Paulo State, southeastern Brazil. Biota Neotrop 8: 127-149.

SEIGEL RA AND FORD NB. 1987. Reproductive ecology. In: Seigel RA et al. (Eds), Snakes, Ecology and Evolutionary Biology. McMillan Publishing Company, New York, USA, p. 210-252.

SHINE R. 1977. Reproduction in Australian elapid snakes II. Female Reproductive Cycles. Aust J Zool 25: 655-666.

SHINE R. 1978. Sexual size dimorphism and male combat in snakes. Oecologia 33: 269-278.

SHINE R. 1980. Ecology of the Australian death adder, Acanthophis antarcticus (Elapidae): evidence for convergence with the Viperidae. Herpetologica 36: 281-289.

SHINE R. 1985. Reproductive biology of Australian reptiles: a search for general patterns. In: Grigg GC et al. (Eds), Biology of Australasian Frogs and Reptiles, Royal Zoological Society of NSW, Sydney, p. 297-303.

SHINE R. 1988. Food habits and reproductive biology of small australian snakes of the genera Unechis and Suta (Elapidae). J Herpetol 22(3): 307-315.

SHINE R. 1992. Relative clutch mass and body shape in lizards and snakes: Is reproductive investment constrained or optimized? Evolution 46: 828-833.

SHINE R. 1993. Sexual dimorphism in snakes. In: Seigel RA and Collins JT (Eds), Snakes: ecology and behavior, New York, McGraw-Hill, p. 49-86.

SHINE R. 1995. A new hypothesis for evolution of viviparity in reptiles. Amer Nat 145: 809-823. 
SHINE R. 2003. Reproductive strategies in snakes. Proc R Soc B 270: 995-1004.

SHINE R, HARLOW PS, KeOGH JS AND BoEADI. 1998. The allometry of life-history traits: insights form a study of giant snakes (Python reticulatus). J Zool 244: 405-414.

SHINE R, OLSSON MM, MOORE IT, LEMASTER MP, GREENE M AND MASON RT. 2000. Body size enhances mating success in male garter snakes. Anim Behav 59: F4-F11.

Sun L, SHINE R, ZHAO D AND TANG Z. 2000. Biotic and abiotic influences on activity patterns of insular pit-vipers (Gloydius shedaoensis, Viperidae) from northeastern China. Biol Conserv 97: 387-98.

TINKLE DW AND GIBBONS JW. 1977. The distribution and evolution of viviparity in reptiles. Misc publ - Mus Zool, Univ Mich 154: 1-55.

TOZETTI AM AND MARTINS M. 2013. Daily and seasonal activity patterns of free range South-American rattlesnake (Crotalus durissus). An Acad Bras Cienc 85: 1047-1052.

TozetTi AM, Vetorazzo V AND Martins M. 2009. Short-term movements of the South American rattlesnake (Crotalus durissus) in southeastern Brazil. Herpetol J 19: 201-206.

VALdujo PH, NogueIRA C AND MARTINS M. 2002. Ecology of Bothrops neuwiedi paoloensis (Serpentes: Viperidae: Crotalinae) in the Brazilian Cerrado. J Herpetol 2: 169176.

VITT LJ. 1983. Ecology of an anuran eating guild of terrestrial tropical snakes. Herpetologica 39: 52-66.

WAECHTER JL. 1985. Aspectos ecológicos da vegetação de restinga no Rio Grande do Sul, Brasil. Comun Mus Ci PUCRS Sér Bot 33: 49-68.

ZAHER H, GRAZZIOTIN FG, CADLE JE, MURPhy RTW, MOURA-LEITE JC AND BONATO SL. 2009. Molecular phylogeny of advanced snakes (Serpentes, Caenophidia) with an emphasis on South American Xenodontines: A revised classification and descriptions of new taxa. Pap Avulsos de Zool 49: 115-153.

ZAR J. 1999. Biostatistical analysis. Upper Saddle River, New Jersey, Prentice Hall, 663 p.

\section{APPENDIX}

The specimens examined from the Herpetological Collection of Universidade Federal do Rio Grande (CHFURG) and Museu de Ciências e Tecnologia da Pontifícia Universidade Católica do Rio Grande do Sul (MCP): MCP14243, CHFURG769, CHFURG770, CHFURG809, CHFURG870, CHFURG871, CHFURG898, CHFURG914, CHFURG1036, CHFURG1075, CHFURG1102, CHFURG1103, CHFURG1104, CHFURG1105, CHFURG1106, CHFURG1186, CHFURG1187, CHFURG1188, CHFURG1189, CHFURG1273, CHFURG1366, CHFURG1367, CHFURG1411, CHFURG1414, CHFURG1422, CHFURG1423, CHFURG1476, CHFURG1496, CHFURG1497, CHFURG1498, CHFURG1499, CHFURG1538, CHFURG1564, CHFURG1565, CHFURG1566, CHFURG1567, CHFURG1740, CHFURG1741, CHFURG1812, CHFURG1830, CHFURG1831, CHFURG1832, CHFURG1833, CHFURG1834, CHFURG1836, CHFURG1838, CHFURG1839, CHFURG1840, CHFURG1841, CHFURG1843, CHFURG1847, CHFURG1849, CHFURG1880, CHFURG1881, CHFURG1887, CHFURG1889, CHFURG1893, CHFURG1911, CHFURG1912, CHFURG1913, CHFURG1914, CHFURG1916, CHFURG1917, CHFURG1918, CHFURG1919, CHFURG1920, CHFURG1921, CHFURG1922, CHFURG1923, CHFURG1924, CHFURG1925, CHFURG1928, CHFURG1988, CHFURG1997, CHFURG2152, CHFURG2153, CHFURG2357, CHFURG2358, CHFURG2359, CHFURG2360, CHFURG2361, CHFURG2362, CHFURG2363, CHFURG2364, CHFURG2365, CHFURG2366, CHFURG2367, CHFURG2368, CHFURG2512, CHFURG2513, CHFURG2514, CHFURG2515, CHFURG2516, CHFURG2517, CHFURG2518, CHFURG2519, CHFURG2520, CHFURG2521, CHFURG2522, CHFURG2523, CHFURG2524. 